\title{
A razão prática schopenhaueriana e a ação por máximas
}

\author{
Katia Santos \\ Mestre em Filosofia pela FFLCH-USP. \\ E-mail: katiasantos@usp.br.
}

RESUMO: Este texto aborda a noção de razão prática de Arthur Schopenhauer. Esse filósofo recusa os atributos que Kant atribui à razão, o qual entende que tal faculdade pode assumir um aspecto prático de condução das ações humanas. Schopenhauer, com outra visão da razão, não aceita também a ideia kantiana segundo a qual uma ação moral é aquela realizada racionalmente. Contudo, nosso filósofo admite um uso prático para a razão, fundado nos mesmos princípios da ética estóica. Assim, de um lado, apresentaremos a crítica de Schopenhauer à razão prática kantiana e, de outro, sua tese do uso prático dessa faculdade.

PALAVRAS-CHAVE: Kant, Schopenhauer, razão prática.

ABSTRACT: This paper examines the concept of practical reason by Arthur Schopenhauer. This philosopher denied the privileges that Kant confers on the reason, which believes that it may take a practical driving of human actions. Schopenhauer, with another view of reason, also not accepts the Kantian idea according to which moral action is that performed reasonably. However, our philosopher admits a practical use for the reason, based on the same principles of Stoic ethics. Thus, on one hand, we present the critique of Kantian practical reason that Schopenhauer made and, on the other, his thesis on the practical use of that power.

KEYWORDS: Kant, Schopenhauer, practical reason.

\section{Introdução}

O texto apresentado a seguir foi elaborado a partir de uma pesquisa de mestrado que realizamos, na FFLCH-USP, acerca do problema da liberdade na filosofia de Schopenhauer. As alterações realizadas foram no sentido de clarificar a escrita. Com efeito, de acordo com Schopenhauer, as ações humanas passam ao largo da razão. A conduta dos indivíduos é determinada por uma relação entre sua vontade e os motivos, pertencentes às circunstâncias empíricas externas. A razão, para o filósofo, não possui a capacidade de determinar os atos e não pode ser prática, no sentido elaborado por Kant. Assim, Schopenhauer critica a noção kantiana, pois considera que essa faculdade se relaciona apenas com o conhecimento abstrato e não interfere na causalidade natural. Além de mostrar a incompatibilidade de uma razão prática com seu próprio pensamento, a refutação dessa ideia seria parte da intenção do filósofo de afastar o dogmatismo da filosofia, como mostra Maria Lúcia Cacciola: 
As objeções a Kant ganham em clareza se considerarmos as preocupações fundamentais que as movem. A mais importante é expulsar qualquer resquício dogmático da filosofia de Kant, que Schopenhauer detecta na inferência da coisa-em-si como causa e na admissão de uma razão prática ao lado de uma teórica e, acima de tudo, nos postulados de Deus, imortalidade da alma e liberdade, exigidas pelo Soberano Bem, união entre virtude e felicidade, ponto culminante da Crítica da razão prática ${ }^{1}$.

Não obstante, no $\S 16$ de $O$ Mundo como vontade e representação e no capítulo 16 de seus Complementos, Schopenhauer apresenta o que entende ser um uso prático possível da razão e, nos "Aforismos sobre a sabedoria da vida", de Parerga e paralipomena, elabora máximas que poderiam servir para guiar nossa conduta. Claro está que, quando Kant escreve sobre a lei moral e as máximas das ações, está tratando de algo completamente distinto do uso prático da razão e das máximas no sentido atribuído por Schopenhauer. Kant reflete sobre a razão prática com vistas estabelecer e fundamentar as ações moralmente boas, enquanto Schopenhauer pensa nela como uma espécie de "satisfação racional" da vontade, visando a uma vida o menos ruim possível. De acordo com isso, o que nos propomos neste trabalho é compreender o uso possível da razão nos atos humanos e o estatuto da ação por máximas na filosofia de Schopenhauer. Para tanto, entendemos ser necessário investigar alguns aspectos da razão prática kantiana e a crítica que Schopenhauer faz a ela para, em seguida, analisar o uso prático possível atribuído à razão pelo nosso filósofo e o modo como ele descreve as máximas para nossa conduta.

\section{A razão prática kantiana e a crítica de Schopenhauer}

Kant define as proposições práticas como aquelas que contêm uma determinação universal da vontade e agrupam sob si diversas regras para a ação. A vontade, por seu turno, é entendida por ele como

uma faculdade de determinar a sua causalidade [dos entes racionais] pela representação de regras, por conseguinte, na medida em que são capazes de ações segundo proposições fundamentais, por conseguinte, também

1 CACCIOLA, M.L. "O intuitivo e o abstrato na filosofia de Schopenhauer". In: SALLES, João Carlos (org.). Schopenhauer e o idealismo alemão, p. 107 et. seq. 
segundo princípios práticos a priori (pois só estes têm aquela necessidade que a razão exige para a proposição fundamental) ${ }^{2}$.

Na condição de proposições subjetivas ou máximas, as proposições seriam válidas apenas para a vontade do sujeito, enquanto na condição de leis práticas ou objetivas, seriam válidas para a vontade de todo ser racional em geral ${ }^{3}$. Para Kant, desse modo, as leis práticas relacionam-se com a razão pura, que deve ser o fundamento suficiente para a determinação absoluta da vontade ${ }^{4}$. Em Fundamentação da Metafísica dos Costumes, o filósofo explica que

tudo na natureza age segundo leis. Só um ser racional tem a capacidade de agir segundo a representação de leis, isto é, segundo princípios, ou: só ele tem vontade. Como para derivar as ações das leis é necessária a razão, a vontade não é outra coisa senão razão prática ${ }^{5}$.

No entanto, as proposições não são leis às quais inevitavelmente nos submetemos, pois, diz o filósofo, "no que é prático a razão tem que ver com o sujeito, ou seja, com a faculdade de apetição, com cuja natureza particular a regra pode conformar-se de múltiplos modos"6. Em vista disso, as leis práticas não podem ficar sob uma condição problemática em relação à vontade, isto é, não podem ter apenas a possibilidade de determinar a ação, mas devem determiná-la de modo absoluto. Precisam ser incondicionais e concebidas $a$ priori, ou seja, devem ser determinadas absoluta e imediatamente pela própria regra, que passa a ser lei moral ${ }^{7}$. A consciência dessa lei fundamental, diz Kant, é um factum da razão, pois não pode ser inferida de dados antecedentes, mas se impõe a nós como uma proposição sintética $a$ priori $^{8}$. Como afirma Kant, não se trata de um fato empírico, mas de um único

${ }^{2}$ KANT, I. Crítica da Razão Prática, p. 109.

${ }^{3}$ Ibidem, p. 65.

${ }^{4}$ Ibidem, p. 67.

5 KANT, I. Fundamentação da Metafísica dos Costumes, p. 47.

${ }^{6}$ KANT, I. Crítica da Razão Prática, p. 69.

${ }^{7}$ Em Fundamentação da Metafísica dos Costumes, Kant explica do seguinte modo: "Princípios empíricos nunca servem para sobre eles fundar leis morais. Pois a universalidade com que elas devem valer para todo os seres racionais sem distinção, a necessidade prática incondicional que por isso lhes é imposta, desaparece quando o fundamento dela se deriva da particular constituição da natureza humana ou das circunstâncias contingentes em que ela está colocada". KANT, I. Fundamentação da Metafisica dos Costumes, p. 87.

${ }^{8}$ Em nota de Fundamentação da Metafísica dos Costumes, Kant escreve a respeito da síntese prática: "Eu ligo à vontade, sem condição pressuposta de qualquer inclinação, o acto a priori, e portanto necessariamente (posto que só objetivamente, quer dizer partindo da idéia de uma razão que teria pleno poder sobre todos os móbiles subjetivos). Isto é, pois, uma proposição prática que não deriva analiticamente o querer de uma ação de um outro querer já pressuposto (pois nós não possuímos uma vontade tão perfeita), mas que o liga 
factum da razão pura, que se proclama como originariamente legislativa ${ }^{9}$. Por conseguinte, sendo a lei prática um produto da razão, e não sendo a razão o fundamento total de determinação da nossa vontade, a regra precisa ser um imperativo, isto é, caracterizar um "dever-ser que expressa a necessitação objetiva da ação"10. A lei deve caracterizar-se pela universalidade e pela necessidade, para que, de fato, seja a razão aquilo que determina a vontade. Nessa medida, enquanto leis apodícticas, os imperativos valem objetivamente e diferem das máximas, que são proposições subjetivas.

Kant distingue os imperativos entre os hipotéticos, que determinam as condições causais com vistas a um efeito, e os categóricos, os únicos que podem ser leis morais, na medida em que determinam somente a vontade enquanto tal. As máximas, para Kant, são proposições fundamentais, mas não imperativos ${ }^{11}$. Do mesmo modo, os imperativos hipotéticos, que não determinam a vontade enquanto tal mas com vistas a um efeito, são preceitos práticos, mas não leis. As leis têm de determinar incontinente a vontade, isto é, independentemente das condições necessárias para produzir o efeito. Assim, a condição para que os imperativos sejam leis é que sejam categóricos, pois é isso que lhes garantirá a necessidade e a independência das condições patológicas e contingentes em relação à vontade $^{12}$. Por conseguinte, posto que somente a razão pode formular regras necessárias, sua legislação deve pressupor somente a si mesma, pois, diz Kant, "a regra só é objetiva e universalmente válida se vale independentemente de condições subjetivas e contingentes, que distinguem um ente racional de outro" ${ }^{13}$. Sobre esse ponto, são interessantes as considerações de O. Külpe:

A base fundamental da lei moral não está no que separa os homens, nas particularidades do temperamento, do espírito e do caráter, mas no que os une, que é a razão. O imperativo moral poderia formular-se também desse modo: procede sempre como um ser racional. A exclusão de todo elemento material entre os motivos determinantes da vontade moral deu lugar ao reproche de formalismo, freqüentemente dirigido contra Kant. Este filósofo não tem geralmente em conta os motivos, objetos ou fins da

imediatamente com o conceito da vontade de um ser racional, como qualquer coisa que nele não está contida". KANT, I. Fundamentação da Metafisica dos Costumes, p.57 et. seq.

${ }^{9}$ KANT, I. Crítica da Razão Prática, p. 107.

${ }^{10}$ Ibidem, loc. cit.

${ }_{11}$ Ibidem, p. 69.

${ }_{12}$ Ibidem, p. 71.

${ }^{13}$ Ibidem,loc.cit. 
vontade, mas só fixa sua atenção em se a vontade pode servir de lei para todo o possível e que, em conseqüência, não implique contradição ${ }^{14}$.

Com efeito, o princípio da moralidade como pensado por Kant está associado à razão e não se restringe ao homem, estendendo-se a todo ser finito que a possui. A lei moral, a saber, "age segundo uma máxima que possas ao mesmo tempo querer que ela se torne lei universal", é entendida como o princípio de onde todos os imperativos podem ser racionalmente derivados ${ }^{15}$. Embora, na condição de seres racionais, possamos pressupor a existência de uma vontade pura em nós, enquanto seres finitos somos afetados por motivos sensíveis. Em virtude disso, a lei moral tem de ter a forma de uma obrigação, e a vontade do indivíduo tem de estar com ela numa relação de dependência, de obrigação, isto é, de "necessitação de uma ação que se chama, por isso, dever" ${ }^{16}$. A esse respeito, em História da Filosofia Alemã, E. Bréhier afirma:

A idéia fundamental da filosofia prática de Kant é que o dever comande à vontade humana por uma lei, a lei moral, que emana da Razão Pura; com efeito, o dever se impõe ao homem com uma universalidade que é a marca autêntica da Razão. É a mesma Razão, a faculdade do universal e do incondicionado, que vimos embaraçar-se na busca da coisa-em-si e que, agora, no seu uso prático, manifesta-se sob aspecto de uma lei que comanda a ação. Obrigação moral e racionalidade são, portanto, duas idéias que se penetram, porque uma e outra implicam universalidade ${ }^{17}$.

Para que uma ação tenha valor moral, a lei que determina sua máxima deverá obrigar imediatamente a vontade, sem o concurso de sentimento de nenhuma espécie. Se, diz Kant, uma ação for executada em respeito à lei moral, mas tiver um sentimento pressuposto na determinação da vontade, a ação terá legalidade, mas não moralidade ${ }^{18}$.

\footnotetext{
14 KÜLPE, O. Kant, p. 128 et. seq.

15 KANT, I. Fundamentação da Metafísica dos Costumes, p. 59.

16 KANT, I. Crítica da Razão Prática, p. 71. Em Fundamentação da Metafísica dos Costumes, Kant explica do seguinte modo: "Dever é a necessidade de uma ação por respeito à lei. Pelo objeto, como efeito da ação em vista, posso eu sentir em verdade inclinação, mas nunca respeito, exatamente porque é simplesmente um efeito e não a atividade de uma vontade. [...] Ora, se uma ação realizada por dever deve eliminar totalmente a influência da inclinação e com ela todo o objeto da vontade, nada mais resta à vontade que a possa determinar do que a lei, objetivamente, e, subjetivamente, o puro respeito por esta lei prática, e por conseguinte a máxima que manda obedecer a essa lei, mesmo com prejuízo de todas as minhas inclinações”. KANT, I. Fundamentação da Metafísica dos Costumes, p. 31.

${ }_{17}$ BRÉHIER, E. Histoire de la philosophie allemande, p. 74 et.seq (tradução nossa).

18 KANT, I. Crítica da Razão Prática, p. 249.
} 
No entender de Kant, a razão pura prática confere realidade à liberdade transcendental, entendida no sentido de causalidade incondicionada. Embora, no âmbito especulativo, o conceito de liberdade permaneça problemático e possa apenas ser pensado, a realidade dele seria provada pela lei apodíctica da razão prática. E, a partir da sua realidade, o conceito de liberdade atribuiria objetividade aos conceitos de Deus e de imortalidade da alma, que são também problemáticos do ponto de vista especulativo. Com isso, diz Kant, "fecha-se a abóbada" de todo o edifício de um sistema da razão pura, que engloba a prática e a especulativa ${ }^{19}$. Por ser a condição da lei moral, a possibilidade da liberdade ser-nos-ia dada a priori, enquanto as idéias de Deus e da imortalidade da alma seriam derivadas do uso prático da razão ${ }^{20}$. A respeito das duas últimas idéias, não poderíamos afirmar a efetividade e sequer a possibilidade, mas elas ficariam como condições de aplicação da vontade à lei moral, dada a priori. Nesse sentido, Deleuze explica que

[...] a determinação prática não incide sobre as três Idéias da mesma forma. Só a Idéia de liberdade é imediatamente determinada pela lei moral: a liberdade, por conseguinte, é menos um postulado do que uma "matéria de fato" ou objeto de uma proposição categórica. As duas outras idéias, como "postulados", são apenas condições do objeto necessário de uma vontade livre $[\ldots]^{21}$.

Em nota do prefácio da Crítica da Razão Prática, Kant esclarece a relação de condicionamento entre a lei moral e a liberdade. Ele afirma que "a liberdade é sem dúvida a ratio essendi da lei moral, mas que a lei moral é a ratio cognoscendi da liberdade" 22 . Assim, por um lado, é o pensamento a priori da lei moral o que autoriza a admitir a existência da liberdade e, por outro, se não existisse liberdade alguma, a lei moral não seria possível para nós ${ }^{23}$. Portanto, segundo Kant, é forçoso admitirmos a possibilidade da liberdade, mesmo sem conhecimento teórico dela. Em comparação com as provas da razão especulativa, o fundamento encontrado aqui é subjetivo e, no entanto, diz Kant, é objetivamente válido para a razão pura prática. A necessidade subjetiva de admitir a liberdade não acrescenta

\footnotetext{
19 Ibidem, p. 5.

20 Ibidem, p. 9.

21 DELEUZE, G. A filosofia crítica de Kant, p. 48.

22 KANT, I. Crítica da Razão Prática, p. 7

23 Ibidem, loc. cit.
} 
nada ao conhecimento teórico dela, embora "sua possibilidade, que antes não passava de problema e aqui se torna asserção, seja dada, e assim o uso prático da razão é conectado com os elementos do uso teórico" 24 . Como mostra Bréhier, com esse raciocínio

[...] ele [Kant] funda também a possibilidade da moral. Mas é necessário acrescentar que a noção que temos de nossa causalidade livre, enquanto númeno, não estende de modo algum nosso conhecimento do mundo numenal; porque concebemos essa característica do númeno de ser uma causa livre, sem ter por isso sua intuição ${ }^{25}$.

Em suma, o uso moral da razão fundamentaria os conceitos de liberdade, Deus e imortalidade, embora de forma totalmente diferente do modo especulativo, isto é, trata-se de um uso prático, sem o conhecimento do supra-sensível. Não obstante, apesar da crítica especulativa kantiana, o supra-sensível permanece existindo, na medida em se que pressupõe uma coisa-em-si como fundamento dos objetos. A razão prática, diz Kant, obteve a realidade para a liberdade enquanto objeto supra-sensível, confirmando assim "mediante um factum o que lá meramente podia ser pensado"26. Por conseguinte, para que haja uma causalidade por liberdade ao lado da causalidade natural, é preciso que o homem seja tomado como ente em si no tocante à lei moral. Como afirma Deleuze,

Parece, portanto, que a razão prática, ao conferir ao conceito de liberdade uma realidade objetiva, legisla precisamente sobre o objeto deste conceito. A razão prática legisla sobre a coisa-em-si, sobre o ser livre enquanto coisa-em-si, sobre a causalidade numenal inteligível de um tal ser, sobre o mundo supra-sensível formado por tais seres. [...] A lei moral é a lei da nossa existência inteligível, isto é, da espontaneidade e da causalidade do sujeito como coisa em $\mathrm{si}^{27}$.

Buscando alicerçar sua própria ética, Schopenhauer critica em detalhes a ética kantiana, em Sobre o fundamento da moral, seguindo pari passu a exposição de Fundamentação da Metafísica dos Costumes. Ele investe, principalmente, contra o imperativo categórico, o qual entende ser um apoio já antigo da ética, usado abusivamente pelos filósofos da sua época. Para ele, “a Razão Prática e o imperativo categórico de Kant

\footnotetext{
${ }^{24}$ Ibidem, p. 11.

25 BRÉHIER, E. op. cit., p. 77.

${ }^{26}$ KANT, I. Crítica da Razão Prática, p. 15.

27 DELEUZE, G. op. cit., p. 38.
} 
são suposições injustificadas, infundadas e inventadas [...]"28. Um aspecto importante da crítica schopenhaueriana é que, de acordo com ele, embora Kant tenha tido o mérito de purificar a ética do eudemonismo presente em antigos e modernos, deixou escapar um vínculo entre virtude e felicidade, na idéia de Soberano Bem. Tanto antigos quanto modernos situariam a virtude como meio para que a felicidade fosse alcançada, mas, conforme Schopenhauer, não é possível justapor virtude e felicidade.

Um dos principais pontos da crítica de Schopenhauer é a afirmação de que a ética kantiana é apresentada como algo independente da experiência, como algo transcendental ou metafísico. Para ele, ao contrário, as ações humanas não possuem um significado que ultrapassa toda a possibilidade da experiência, nem realizam a passagem que leva ao mundo inteligível das coisas-em-si. A atribuição de uma faculdade prática à razão, possibilitada pelo conceito que Kant elabora desta última, teria sido responsável pela sua volta ao dogmatismo. Como mostra Maria Lúcia Cacciola,

É no próprio núcleo da filosofia transcendental, na noção de razão, que Schopenhauer localiza o germe que teria sido responsável pelo retorno ao dogmatismo. A saber, esta razão, investida do poder de, a partir de si mesma, produzir idéias e buscar legitimamente o incondicionado, teria esquecido suas limitações e se transformado, no interesse prático, na fonte de uma causalidade por liberdade, de onde emanaria um dever moral absoluto, um imperativo categórico. Os poderes conferidos à razão de buscar naturalmente o incondicionado possibilitam a hipóstase da razão teórica na prática ${ }^{29}$.

Como se sabe, Schopenhauer funda sua ética na experiência e não em algo supra-sensível, pois a Vontade, que é para ele o núcleo metafísico de todo o existente, não é um fundamento extramundano, mas imanente ao próprio mundo. Assim, afirma Cacciola, Schopenhauer admite a limitação do conhecimento, exposta na parte crítica do sistema kantiano, mas não o "supra-sensível e a razão prática (por onde o dogmatismo banido retornaria por contrabando)" 30 .

Dessa forma, já no conceito de ética Schopenhauer identifica o que teria sido um erro de Kant, qual seja, o de entender que uma filosofia prática não deva referir-se ao

\footnotetext{
28 SCHOPENHAUER, A. M/M. I, 2, p. 16.

29 CACCIOLA, M. L. Schopenhauer e a questão do dogmatismo, p. 20.

30 Ibidem, p. 16.
} 
mundo factual, mas propor as leis para o devir. Segundo Schopenhauer, isso é uma petitio principii, e ele então pergunta: "Quem nos diz que há leis às quais nossas ações devem submeter-se? Quem vos diz que deve acontecer o que nunca acontece? O que vos dá o direito de antecipá-lo e logo impor uma ética na forma legislativo-imperativa como a única para nós possível?" 31. Schopenhauer, como dito, considera que o fenômeno ético se encontra no próprio mundo, e que o filósofo não deve prescrever normas, mas esclarecer o que de fato acontece. As leis morais e o conceito de dever, que deslocam a ética kantiana para o supra-sensível são, para ele, extraídas do Decálogo Mosaico e admitidas antes de qualquer investigação. A moral kantiana, então, teria tomado da teologia sua forma de mandamento, apenas disfarçando os pressupostos teológicos com os conceitos de dever absoluto, leis morais e obrigação.

Conforme Schopenhauer, Kant erra ainda ao formular a noção de dever absoluto, pois ele nunca poderia ser incondicionado, já que só tem sentido se referido a um castigo ou a uma recompensa. Dever incondicional seria algo contraditório, pois, diz ele,

cada dever é também necessariamente condicionado pelo castigo ou pela recompensa e assim, para falar a linguagem de Kant, essencial e inevitavelmente hipotético e jamais, como ele afirmou, categórico. Por isso o dever absoluto é simplesmente uma contradictio in adjecto ${ }^{32}$.

Pela mesma razão, o dever fundar-se-ia no egoísmo do agente e não estaria necessariamente ligado à moral. Isso é provado, segundo o filósofo, pelo fato de que Kant teve de postular a imortalidade da alma como recompensa, bem como um recompensador do cumprimento do dever. A moral kantiana, no fundo, seria eudemonista a como todas as outras, já que estaria ancorada na busca do bem próprio. E a heteronomia, criticada por Kant, teria sido reintroduzida sub-repticiamente, sob o nome de Soberano Bem, cuja noção unifica virtude e felicidade ${ }^{33}$. No fim de contas, a forma imperativa da moral teológica teria sido transportada, sem prova, para a moral filosófica, por meio de uma de inversão:

Dito de forma abstrata, o procedimento de Kant é o de ter dado como resultado aquilo que teria de ter sido o princípio ou o pressuposto (a

31 SCHOPENHAUER, A. M/M, II, 4, p. 21.

${ }^{32}$ SCHOPENHAUER, A. M/M, II, 4, p. 24.

${ }^{33}$ Ibidem, p. 25. 
teologia) e de ter tomado como pressuposto aquilo que teria de ter sido derivado como resultado (o mandamento) $)^{34}$.

Em relação à lei moral kantiana, Schopenhauer também censura o fato de ter que ser cognoscível a priori, com independência da experiência externa e interna. Para ele, os conceitos puros a priori, fundamento da moral kantiana, seriam "puras cascas sem caroço" ${ }^{35}$, já que não podem se apoiar em nenhuma experiência. A razão teria sido hipostasiada como algo que existe por si, e válido para todo ser racional, afastando-a de sua ligação com o conhecimento especificamente humano. Segundo Schopenhauer, ao contrário, a inteligência é propriedade de todos animais e a razão, somente da humanidade. Não seria legítimo portanto, pensar a razão fora da sua única espécie, o ser humano, sendo ilegítima também a conclusão de que existiriam seres racionais em abstrato e leis para eles, tomados abstratamente.

Ao transpor o método da filosofia teórica para a prática, Kant teria perdido de vista a noção de que a lei moral deve, como na filosofia teórica, limitar-se ao mero fenômeno. Seguindo a transposição do método, Kant teria concluído, conforme Schopenhauer, que assim como conhecemos a priori as leis do espaço, do tempo e da causalidade, também o fio condutor das ações nos seria dado antes da experiência, manifestando-se como imperativo categórico. $\mathrm{Na}$ verdade, para Schopenhauer, os conhecimentos teóricos a priori expressam meras formas, isto é, funções do intelecto, por meio das quais apreendemos o mundo objetivo. Somente nesse sentido são legisladoras, pois a experiência tem sempre que estar em concordância com elas. No entanto, diz o filósofo, às leis morais isso não se aplica, já que desprezam a experiência e sua aplicação a ela é duvidosa. Em suma, na filosofia teórica, o apriorismo do conhecimento limita-se ao fenômeno, não valendo para as coisas-em-si. A lei moral da filosofia prática, sendo a priori, deveria, da mesma maneira, ser apenas uma forma do fenômeno e não tanger à metafísica.

De acordo com Kant, uma ação moral só tem valor genuíno quando é praticada por dever, sem ligação com tendências ou com inclinações, nem mesmo boas. Schopenhauer, por seu turno, considera que só pela intenção podemos saber o valor moral de um ato, pois é o que pode dizer se ele é louvável ou reprovável. Assim, para Kant, o valor de um caráter estaria ligado à indiferença com que alguém cumpre o seu dever, realizando boas ações não ${ }^{34}$ Ibidem, p. 27.

35 Ibidem, II, 6, p. 33. 
por solidariedade ou simpatia, mas com impassibilidade. Kant, diz Schopenhauer, rejeita inclusive os sentimentos de compaixão e de ternura, reputando-os perturbadores das máximas morais refletidas. Schopenhauer argumenta que com isso, no entanto, retornaríamos à heteronomia, pois um homem impassível só se moveria por medo dos demônios e do castigo ${ }^{36}$.

Tendo Kant definido o conceito de dever como a necessidade de uma ação por respeito à lei, Schopenhauer se pergunta qual é o sentido dessa necessidade. Para ele, ser necessário é ser inevitável, o que não se coaduna com o fato de as ações por dever, em geral, não se realizarem. Ele afirma:

Em que sentido pode-se pois atribuir necessidade a uma tal ação? Já que é justo interpretar um autor sempre pelo mais favorável, digamos que o que ele quer dizer é que uma ação conforme ao dever é necessária objetivamente, mas subjetivamente casual. No entanto não é tão fácil pensar tal coisa quanto dizê-la: onde está pois o objeto desta necessidade objetiva, cujo resultado muitas vezes e talvez nunca se dê na realidade objetiva? ${ }^{37}$.

A expressão "necessidade de uma ação" seria tão somente uma perífrase da palavra dever e a noção de respeito, no fim de contas, uma tentativa de ocultar a origem teológica do conceito de obediência ${ }^{38}$.

Schopenhauer não admite que a razão prática seja uma faculdade especial, irredutível, mas entende que é uma e a mesma com a teórica. Uma vez rejeitado todo o elemento empírico, diz ele, a fundamentação da lei que influenciará a vontade deve basear-se apenas na sua forma, que é a legalidade, e que, por definição, deve ter universalidade. Porém, no fundo, a razão seria prática somente durante a realização do processo de pensamento que leva à lei moral, isto é, enquanto busca o resultado do processo de pensamento. Na prática, essa lei seria impossível em nós, pois o homem não chega por si só à idéia de formulá-la nem de submeter suas ações a ela. Tal idéia só adviria, afirma Schopenhauer, em função de uma motivação moral positiva, anunciada por si mesma, pois somente o que é empírico tem realidade pressuposta. Desse modo, a motivação moral teria de ser empírica e impor-se com força suficiente para superar os

\footnotetext{
${ }^{36}$ Ibidem, p. 38.

37 Ibidem, p. 39.

38 Ibidem, loc.cit.
} 
motivos egoístas, que são fortes e se opõem a ela ${ }^{39}$. Segundo Kant, ao contrário, seria o próprio processo de pensamento a origem de todos os conceitos morais. Então, diz Schopenhauer,

Temos de nos lamentar pelo fato de que puros conceitos abstratos, $a$ priori, sem conteúdo real e sem qualquer tipo de fundamentação empírica, nunca poderiam pôr em movimento pelo menos os homens: de outros seres racionais não posso falar ${ }^{40}$.

Por conseguinte, a fundamentação kantiana da moralidade careceria de realidade e de efetividade, e sua noção de razão prática teria levado à mistificação da própria razão, ao torná-la uma espécie oráculo que anuncia tudo o que deve acontecer ${ }^{41}$. A transmissão da espontaneidade da razão teórica à razão prática teria dado azo também ao surgimento de doutrinas heterogêneas em relação à filosofia crítica, para as quais existiria uma razão que pressente, que percebe e que intui intelectualmente o supra-sensível ${ }^{42}$.

\section{A razão prática schopenhaueriana}

Na verdade, conforme Schopenhauer, a razão possui de fato um uso prático, que é o de possibilitar que as pessoas não se guiem meramente pelas impressões sensoriais, mas também por pensamentos e conceitos. O comportamento racional seria, portanto, aquele em que o indivíduo age refletidamente, tendo máximas fundamentais como seus motivos. Porém, agir racionalmente não significa fazê-lo moralmente, pois é possível praticar o mal usando a razão, assim como realizar o bem sem o concurso dela. É por isso, diz Schopenhauer,

[...] que antes de Kant, jamais ocorreu a alguém identificar o comportamento justo, virtuoso e nobre com o comportamento racional. Têm-se porém distinguido e separado ambos por completo. Um repousa sobre a espécie de motivação, o outro sobre o caráter distintivo das máximas fundamentais ${ }^{43}$.

\footnotetext{
${ }^{39}$ Ibidem, p. 48.

${ }^{40}$ Ibidem, p. 40.

${ }^{41}$ Ibidem, p. 52.

${ }^{42}$ Ibidem, p. 53.

${ }^{43}$ Ibidem, p. 57.
} 
No $\S 16$ de $O$ mundo ... e no capítulo 16 dos Complementos, Schopenhauer expõe o que considera o uso prático possível da razão. De acordo com ele, a presença de conceitos é o que torna a vida humana toto genere diferente da vida dos animais, pois, paralelamente à realidade concreta, temos uma segunda vida in abstracto, que nos possibilita dominar, até certo ponto, nossa natureza animal ${ }^{44}$. A razão faculta-nos a visão de um panorama amplo da vida em seu conjunto, um reflexo do mundo, por meio do qual podemos visualizar seu plano reduzida e abstratamente. Permite-nos conectar os aspectos fragmentários e unilaterais do vivido intuitivamente, resolver as contradições das ações dos indivíduos e extrair conclusões e resultados. Com isso, a razão nos oferece um conhecimento que podemos utilizar na nossa própria vida. Como ele afirma,

Verdadeiramente podemos dizer que aqui a razão se mostra em seu sentido prático: onde quer que a conduta esteja dirigida pela razão, onde os motivos sejam conceitos abstratos, onde o determinante não sejam as representações particulares e intuitivas, nem a impressão do instante que guia ao animal, manifesta-se a razão prática ${ }^{45}$.

Como já dito, para Schopenhauer, o valor ético das ações, não passa pelo raciocínio, pois a razão pode servir para a realização metódica e refletida tanto de atos nobres quanto de vis, tanto das máximas prudentes quanto das imprudentes ${ }^{46}$. O valor da razão não está em oferecer um caráter moral à conduta humana, mas no fato de que, ao guiar suas ações por conceitos, o homem coloca-se um passo a frente dos animais e emancipa-se do jugo do presente e do intuitivo. Sobre isso, ele afirma:

[...] demonstrei que, na teoria, partir de conceitos só conduz a resultados medíocres e que, ao contrário, para se chegar a resultados excelentes deve-se partir da intuição mesma como origem de todo conhecimento. $\mathrm{Na}$ prática acontece totalmente o contrário. Aqui são os animais que estão determinados pela intuição, mas isso é indigno do homem, já que este possui conceitos que guiam sua conduta e, desse modo, emancipa-se do poder do presente intuitivo ao que o animal está incondicionalmente entregue $^{47}$.

\footnotetext{
44 SCHOPENHAUER, A. MVRI, § 16, p. 113.

45 Ibidem, loc. cit.

${ }^{46}$ Ibidem, p. 114.

47 SCHOPENHAUER, A. MVRII, cap. 16, "Sobre o uso prático da razão e sobre o estoicismo”, p. 587.
} 
O melhor uso que poderia ser feito da razão na vida prática seria, segundo o filósofo, seguir os preceitos da ética estóica ${ }^{48}$, fundada na convicção de que devemos buscar não os prazeres, mas a ausência de dor. Os cínicos teriam sido ótimos filósofos práticos, pois utilizaram a razão para viver segundo esse preceito, indo até às últimas conseqüências. "Para conseguir a vida mais livre de dores" - diz Schopenhauer - "escolheram o caminho de maior privação possível, fugindo de todos os prazeres como se se tratasse de armadilhas que acabam por entregar o homem à dor"49. Os estóicos teriam, conforme o filósofo, convertido a prática cínica em teoria, entendendo que não era necessário prescindir dos prazeres na vida concreta. Segundo o estoicismo, poderíamos aproveitar os bens e as alegrias, com desde que tivéssemos claro que eles são inseguros, frágeis e dependentes da fortuna. Nas palavras de Schopenhauer,

[...] os estóicos aperfeiçoaram a teoria da indiferença e da independência às custas da prática, pois reduziram tudo a um processo mental e mediante argumentos, como o que apresenta o primeiro capítulo de Epíteto, sofisticaram-se em todas as comodidades da vida ${ }^{50}$.

Segundo o filósofo, os estóicos estariam penetrados da verdade de que o curso do mundo é absolutamente independente da nossa vontade, e de que os males são inevitáveis. Essa convicção seria a razão última dos conselhos dirigidos à impassibilidade e à indiferença, as quais não permitiriam alegria nem tristeza diante dos acontecimentos da vida, por não estarem em nosso poder. Como diz Schopenhauer,

\footnotetext{
${ }^{48}$ É importante notar que a ética estóica não se relaciona com o moralmente bom, podendo até mesmo ser prejudicial à nossa verdadeira salvação, na medida em que nos torna insensíveis à dor que pode nos levar a negar a Vontade. É o que Schopenhauer afirma em "Contribuições à doutrina da afirmação e da negação do querer-viver", de Parerga e Paralipomena: "Também, pelo mesmo motivo, o estoicismo da mentalidade que oferece resistência ao destino, embora uma boa couraça contra os sofrimentos da vida, é útil para melhor suportar o presente: porém, ele se opõe à verdadeira salvação, pois torna obstinado o coração. Como poderia este ser melhorado por meio dos sofrimentos, se, envolto numa grossa casca pétrea, sequer os percebe? Aliás, um certo grau deste estoicismo não é muito raro. Freqüentemente pode ser afetação e se reconduzir a bonne mine au mauvais jeu*: onde porém se instaura sem dissimulação, origina-se na maior parte das vezes de simples insensibilidades, por carência de energia, vivacidade, sentimento e fantasia, indispensáveis mesmo para um grande sofrimento do coração". SCHOPENHAUER, A. P/P, "Contribuições à doutrina da afirmação e da negação do querer-viver", § 170, p. 233.

* Provérbio francês: Faire bonne mine à mauvais jeu, que significa algo como "fazer cara boa quando as coisas vão mal".

49 SCHOPENHAUER, A. MVRII, cap. 16, "Sobre o uso prático da razão e sobre o estoicismo", p. 592.

${ }^{50}$ Ibidem, p. 596.
} 
É verdade que todos os bens da vida estão em poder da contingência e, por conseguinte, enquanto esta, exercendo seu poder, nos arrebata, seremos infelizes se tivermos depositado neles nossa felicidade. Para escapar a esse destino indigno basta usar corretamente a razão, que fará que não consideremos nunca todos os bens como nossos, mas só como um empréstimo por tempo determinado: assim nunca poderemos perdê-los realmente ${ }^{51}$.

Por conseguinte, a ética estóica seria uma incitação à vida racional, entendida como o uso da razão para evitar ao máximo possível os sofrimentos da vida, e para se alcançar a paz interior e a tranqüilidade de espírito, a $\alpha \tau \alpha \rho \alpha \xi \xi \alpha^{52}$. O uso adequado da razão seria útil também para fazer-nos compreender que o sofrimento deriva da contrariação do querer, levando-nos a olhar com indiferença a não satisfação de um desejo, bem como os males inevitáveis. Nesse sentido, diz Schopenhauer, "todo sofrimento resulta propriamente do desequilíbrio entre o que pedimos ou esperamos e o que se nos dá, desequilíbrio que se encontra evidentemente só no conhecimento e que poderia eliminar-se por meio de um melhor conhecimento" ${ }^{" 53}$. A cólera diante de um evento inesperado seria, assim, resultado de um julgamento errado do mundo e da vida, e a alegria, do mesmo modo, seria a ilusão resultante do desconhecimento das verdades de que nenhuma satisfação é duradoura e de que a roda da fortuna pode girar a qualquer momento. Desse modo, seria preciso não se importar com as circunstâncias externas e viver em harmonia consigo mesmo, ou melhor, com sua própria vontade. Isso pode ser feito, conforme Schopenhauer, se nos determinamos racionalmente, tomando as máximas de nossa conduta da sabedoria estóica ${ }^{54}$.

Em "Aforismos sobre a sabedoria da vida", de Parerga e Paralipomena, Schopenhauer segue as lições estóicas e discorre extensamente sobre máximas para nossa conduta, para que passemos pela vida do melhor modo possível. Na introdução, ele adverte enfaticamente que o assunto não será tratado dos pontos de vista moral e metafísico, mas da perspectiva empírica. Atribui às considerações contidas nesse texto um valor condicional, de um lado, porque se apresentam como parciais e, de outro, porque toda a sua filosofia é contrária à possibilidade de uma eudemonologia. Para o filósofo, o bem-estar ou mal-estar das pessoas depende, essencialmente, de uma constituição que é metafísica, de modo que a

\footnotetext{
51 Ibidem, p. 597.

52 "Imperturbabilidade". SCHOPENHAUER, A. MVRI, § 16, p. 114.

53 Ibidem, p. 115 et. seq.

${ }^{54}$ Ibidem, p. 117.
} 
influência do exterior é sempre mediata. Em função disso, não se deve colocar demasiadas esperanças no potencial das máximas em trazer felicidade.

Com efeito, Schopenhauer mostra que para cada homem há um quantum de felicidade, fixado de acordo com a qualidade da consciência individual. Nisso, segundo ele, homem e animal estariam unidos, pois ambos possuem uma medida de felicidade possível e estão limitados à esfera da natureza ${ }^{55}$. A susceptibilidade para os prazeres mais elevados é dada pelo intelecto, que pode alçar o indivíduo acima dos prazeres meramente sensórios. Porém, diz ele, os dotes intelectuais não podem ser dilatados para além das suas capacidades, de modo que a metade subjetiva de nossa existência é o fundamental ${ }^{56}$. De acordo com isso, essa metade subjetiva tem a vantagem, em relação aos bens que possuímos e ao que representamos aos olhos dos outros, de não se submeter à sorte. Porém, em contrapartida, não está em nosso poder modificá-la, pois ela seria “estabelecido por jure divino" ${ }^{57}$. O que possuímos e o que representamos para os outros, por seu turno, podem ser adquiridos por todos e estão de certo modo em nosso poder, enquanto elementos colocados fora de nós. Desse modo, para o filósofo, podemos empregar em nosso proveito aquilo que somos, nossa personalidade, desenvolvendo as potencialidades que possuímos. Podemos também buscar o modo de vida que nos é, em função delas, mais apropriado ${ }^{58}$. Nesse sentido, ele diz:

Tudo o que aqui podemos fazer é empregar essa personalidade, tal como nos foi dada, em nosso maior proveito; portanto, perseguir apenas as aspirações que lhe correspondem; não buscar senão o desenvolvimento que lhes é apropriado, evitando qualquer outro; não escolher, por

\footnotetext{
55 SCHOPENHAUER, A. P/P, "Aforismos sobre a sabedoria da vida", p. 30.

56 Conforme Schopenhauer, a realidade está dividida entre duas metades: sujeito e objeto. Em nossa vida, essas metades correspondem a uma parte objetiva, que constitui o entorno real em que vivemos, e a uma parte subjetiva, que são as qualidades de nossa vontade, nosso intelecto e nossa sensibilidade. Cf. SCHOPENHAUER, A. P/P, “Aforismos sobre a sabedoria da vida”, p. 29.

57 Ibidem, p. 32.

58 Uma vez alcançada essa sabedoria, alcançaremos o que o filósofo chama de caráter adquirido: "Só pela experiência podemos conhecer o que queremos e o que podemos; enquanto não o sabemos, carecemos de caráter, e o que nos abre os olhos são os golpes adversos. Uma vez que tenhamos aprendido, possuímos o que no mundo se chama caráter, o caráter adquirido. Este não é, portanto, outra coisa que o conhecimento mais perfeito possível da individualidade própria; é o saber abstrato, e por isso claro, das peculiaridades inalteráveis do nosso caráter empírico, assim como a medida e direção de nossas capacidades espirituais e corporais, isto é, de todas as forças e debilidades de nossa própria individualidade". M SCHOPENHAUER, A. MVRI, $\S 55$, p. 331.
} 
conseguinte, senão o estado, a ocupação e o gênero de vida mais adequado a ela ${ }^{59}$.

Não obstante, o que nos interessa no texto dos "Aforismos" é menos a felicidade que podemos obter no mundo, e mais o modo como Schopenhauer aborda as máximas para nossa conduta ${ }^{60}$. A possibilidade de agir conforme máximas é dada pela aptidão humana para a reflexão, isto é, a capacidade fornecida pela razão de operar com conceitos. A reflexão, para Schopenhauer, é a aparência refletida do conhecimento intuitivo, ou melhor, é um reflexo abstrato do intuitivo ${ }^{61}$, o qual possibilita a diferença radical existente na consciência e nos modos de vida de homens e de animais ${ }^{62}$. Entre essas diferenças, está a de viver de acordo com máximas, o que significa escolher racionalmente uma determinada orientação para a conduta, sem atenção às impressões casuais momentâneas. Em $O$ mundo..., ele diz a respeito disso:

Eles [os animais] vivem entregues por completo à impressão do momento, à ação do motivo intuitivo; ele [o homem] é determinado por conceitos abstratos independentes do presente. Por isso põe em prática planos meditados ou age segundo máximas, sem considerar seu entorno nem as impressões acidentais do momento ${ }^{63}$.

Com efeito, no texto dos "Aforismos", Schopenhauer discorre sobre as máximas para as ações, dividindo-as entre aquelas que são gerais e as que se referem à nossa conduta

59 SCHOPENHAUER, A. P/P, “Aforismos sobre a sabedoria da vida”, p. 33.

60 A abordagem das máximas é feita de modo diferente da realizada em Sobre o fundamento da moral. Nesta obra, Schopenhauer fala das máximas que fundamentam a ação moralmente boa, faticamente dada. Do ponto de vista da moral, não valem admoestações ou máximas para orientação antes do ato, mas somente a explicação, a posteriori, do seu princípio. A máxima, aqui, vem em auxílio de uma intuição moral fundamental, na medida em que a reflexão racional serve para elevar a máxima da ação moral a uma resolução firme. Ele afirma: "pois, embora o princípio e o conhecimento abstrato não sejam de modo nenhum a fonte originária ou o primeiro fundamento da moralidade, são, no entanto, indispensáveis para levar uma vida moral, como sendo o depósito, o reservatório, no qual está conservada a disposição nascida da fonte de toda a moralidade, que não flui a todo instante para que, ao surgir o caso em que se aplique, flua daí através de canais emissários". SCHOPENHAUER, A. M/M, III, 17, p. 136 - 137.

61 SCHOPENHAUER, A. MVRI, § 8, p. 64.

62 É importante lembrar que, de acordo com Schopenhauer, para alcançar essas diferenças e realizar todas as potencialidades oferecidas pela razão, é necessário também o concurso da linguagem. Como ele afirma, “ $O$ animal comunica seus sentimentos e sensações mediante gestos e sons; o homem comunica aos demais seus pensamentos por meio da linguagem; ou os oculta também por meio da linguagem. A linguagem é o primeiro produto e a ferramenta necessária de sua razão. [...] Só com a ajuda da linguagem pode a razão levar a cabo suas obras mais importantes, como a ação coordenada de vários indivíduos, a colaboração metódica de milhares de homens, a civilização, o Estado; [...]". SCHOPENHAUER, A. MVRI, § 8, p. 64 et. seq.

${ }^{63}$ Ibidem, $\S 8$, p. 64. 
em relação a nós mesmos, em relação ao próximo, em relação ao curso do mundo e à sorte $^{64}$. Nas máximas gerais, o filósofo enumera três regras. A primeira que, como ele diz, foi enunciada por Aristóteles na sua Ética a Nicômaco, seria a regra mais fundamental de todas as máximas: "o sábio persegue a ausência de dor e não o prazer" ${ }^{\circ}$. De acordo com essa máxima, um tratado de eudemonologia não deve versar sobre a vida feliz, mas sobre a menos infeliz ${ }^{66}$. Para o filósofo, tal ponto de vista se justifica porque o prazer é negativo, enquanto a dor é positiva, ou seja, o que se manifesta como positivo são os obstáculos à vontade do indivíduo, de modo que o prazer é sentido na supressão de tais obstáculos. Se observarmos essa regra, nossa atenção dirigir-se-á para as fugas possíveis à dor, seremos prudentes $^{67}$ e evitaremos os males. Seremos tão felizes quanto é possível de fato, pois em vez de buscar um simulacro de felicidade, algo sempre imaginário, escaparemos das dores, que são efetivamente reais. Como diz o filósofo,

se, pelo contrário, se obedece essa regra aqui exposta; se se estabelece o plano da vida com o propósito de cortar os sofrimentos, isto é, fugir da necessidade, da enfermidade e de toda outra infelicidade, então o fim é real; poder-se-á obter algo e tanto mais quanto o plano tenha estado mais isento desse prejuízo da persecução do bem-estar positivo ${ }^{68}$.

A segunda máxima geral afirma que, para se avaliar a condição de um homem no tocante à sua felicidade, devemos saber o que o entristece e não o que o deixa feliz. Isso porque, diz o filósofo, o que o aflige é que dará a medida da infelicidade a que está sujeito. A terceira máxima manda reduzirmos a quantidade de pretensões, isto é, de expectativas de bem-estar, pois assim haverá menos chances de sermos malsucedidos. Temos de levar em conta que a vida é curta e que o tempo modifica nossas potencialidades, de modo a formular pretensões em proporção com os recursos de que dispomos. Ao invés de buscar a satisfação nos acontecimentos de nossa vida, devemos procurar o conhecimento.

Nas máximas em relação à nossa conduta para com nós mesmos, Schopenhauer enumera 17 regras, as quais são, fundamentalmente, conseqüências extraídas das máximas

\footnotetext{
${ }^{64}$ SCHOPENHAUER, A. P/P, “Aforismos sobre a sabedoria da vida”, p. 133.

${ }^{65}$ Ibidem, p. 134.

${ }^{66}$ Ibidem, p. 135.

${ }^{67}$ No primeiro livro de MVRI, Schopenhauer define a prudência como a acuidade do entendimento em perceber as relações causais na vida prática. Seria o melhor uso que pode ser feito do entendimento para o alcance dos objetivos da vontade. Cf. SCHOPENHAUER, A. MVRI, 2005, § 6.

68 SCHOPENHAUER, A. P/P, “Aforismos sobre a sabedoria da vida”, p. 137.
} 
gerais e da preponderância da subjetividade na determinação da felicidade. Como seria ocioso referir todas, mencionaremos apenas as mais importantes para o nosso propósito ${ }^{69}$. Com efeito, a quarta máxima recomenda não prestarmos atenção aos dias da nossa vida tomados singularmente, mas olhá-los em seu conjunto, em seu caráter total. É preciso buscar o conhecimento de nós mesmos, isto é, do que queremos realmente, do que é essencial à nossa felicidade e do que é acidental, reconhecer nossa vocação e nosso papel no mundo. Seria uma tentativa de corrigir o fato de que, embora as ações se dêem conforme o caráter individual, via de regra agimos de modo inconsciente, sem ter clareza de nossa própria orientação.

A sétima máxima ordena que prestemos atenção ao que ocupa nossa consciência, pois é isso, no fim das contas, que importa à nossa dita ou à nossa desdita. É recomendável que nos dediquemos ao estudo e ao trabalho intelectual, que oferecem tranqüilidade e recolhimento. A oitava máxima preceitua que vivamos com prudência, extraindo ensinamentos da experiência, e, para isso, é interessante comparar nossas opiniões antigas com as atuais, os projetos antigos com os resultados que obtiveram e recapitular as situações vividas. Esses procedimentos evitariam que nos perdêssemos no tumulto dos afazeres cotidianos, em confusões de pensamentos desordenados resultantes da soma das impressões exteriores. Seria útil, aconselha o filósofo, escrever um diário.

A décima segunda máxima manda interiorizarmos a verdade segundo a qual tudo no mundo ocorre necessariamente, de modo a não lamentarmos quando uma desgraça qualquer acontece. Não devemos sofrer com a ideia de que algo poderia ter sido evitado, nem com a meditação sobre o que poderia tê-lo evitado. Porém, não nos devemos escusar dos erros que tenhamos cometido por atos negligentes ou temerários; nesses casos, é importante confessar a culpa para evitar reincidências no futuro. A décima terceira prescreve não dar asas à fantasia, tanto em relação às nossas aspirações quanto a desgraças impossíveis. Nossos interesses têm de ser pensados racional e impassivelmente, ou melhor, "devemos considerar o que interessa à nossa felicidade ou infelicidade somente com os olhos da razão e do juízo; é preciso antes de tudo refletir seca e friamente, e depois operar com noções in abstracto"70. A décima oitava máxima vai no mesmo sentido, e ordena que guiemos nossos trabalhos não

${ }^{69}$ Cf. SCHOPENHAUER, A. P/P, "Aforismos sobre a sabedoria da vida", cap. V, item 2, "Máximas concernentes a nossa conduta para com nós mesmos", p. $143-180$.

${ }^{70}$ Ibidem, p. 168. 
pela imaginação, mas por noções claras. O que nos faria errar amiúde não seriam as noções e os juízos, mas imagens ilusórias colocadas no lugar dos conceitos.

A décima sexta máxima prescreve abstinere et sustinere, ou seja, abster-se e sustentar-se. De acordo com ela, temos de exercer uma coação sobre nós mesmos, limitando nossos desejos, ambições e cólera, recordando a todo momento que alcançaremos somente uma pequena parte do que desejamos e que inúmeros males acometem a todos, sem exceção. A décima nona indica que se domine a impressão do presente e visível que, mais enérgico e pulsante do que o pensamento abstrato, retira o repouso do espírito e estorva seus desígnios. O que é presente e visível age prontamente, enquanto os pensamentos e razões tomam tempo e exigem tranqüilidade. Caso não consigamos dominar a impressão que nos causam as circunstâncias, aconselha Schopenhauer: "o melhor que temos que fazer, então, é neutralizar uma impressão com a impressão contrária; por exemplo, a impressão de uma ofensa, visitando as pessoas que nos estimam, a impressão de um perigo que nos ameaça, pela visão dos meios de evitá-1o"71.

As máximas relativas à nossa conduta para com o próximo são em número de 25 , e assim como no caso das anteriores, ressaltaremos apenas as que melhor servem ao nosso propósito, contentando-nos em relacionar somente quatro delas ${ }^{72}$. A vigésima primeira máxima nos diz que, na nossa trajetória, temos de ser circunspectos para evitar as perdas, e indulgentes, para desviar-nos das disputas. É preciso atentar à verdade de que as individualidades são forjadas pela própria natureza, de modo que não podemos rechaçá-las, ainda que se trate da "mais má, a mais lastimosa e a mais ridícula"73. Devemos compreender que a personalidade é algo imutável, com fundamento metafísico, pois "ninguém pode modificar sua individualidade própria, isto é, seu caráter moral, suas faculdades intelectuais, seu temperamento, sua fisionomia, etc."74. A vigésima oitava máxima relativiza a que referimos antes, propondo que não sejamos demasiado amáveis nem indulgentes com os outros, para não deixá-los mal-acostumados. O ideal, diz Schopenhauer, é não ter necessidade real da outra pessoa e fazer com que ela saiba, para que não nos trate com arrogância e presunção.

\footnotetext{
71 Ibidem, p. 177.

72 Cf. SCHOPENHAUER, A. P/P, "Aforismos sobre a sabedoria da vida”, cap. V, item 3, "Máximas concernentes a nossa conduta para com o próximo", p. $181-206$.

73 Ibidem, p. 181.

74 Ibidem, loc. cit.
} 
A trigésima máxima é de todas a mais interessante para refletirmos sobre a razão prática, pois se refere à orientação dos indivíduos por máximas e noções abstratas. Com efeito, Schopenhauer afirma que "nenhum caráter é tal que possa ser abandonado a si mesmo; necessita ser guiado por noções e máximas" ${ }^{75}$. Não se trata, naturalmente, de substituir a natureza inata por um caráter adquirido por meio de deliberação racional, pois nenhum caráter pode ser totalmente artificial. Porém, segundo o filósofo, é possível e desejável que nos guiemos na nossa vida prática por máximas abstratas, com as quais nos educamos pelo exercício constante. Como ele diz, nas máximas abstratas "ocorre o mesmo que em todas as instruções e direções práticas: compreender a regra é uma coisa, e aprender a aplicá-la é outra. A primeira se adquire de um só golpe, pela inteligência; a segunda, pouco a pouco, pelo exercício"76. Para essa educação própria, seriam necessários bastante tempo e esforço individual, porque ela implica oposição à nossa natureza, procurando impor-lhe uma forma artificial. Por fim, a trigésima sétima máxima nos insta a não ver os outros como modelos das nossas ações, pois as circunstâncias e as relações, bem como o caráter, jamais coincidem. Precisamos refletir muito e seriamente sobre nosso caráter, para que possamos agir conforme a ele, ou melhor, "a originalidade é, pois, indispensável ainda na vida prática; sem ela o que se faz não concorda com o que se é",77.

Nas máximas referentes à nossa conduta frente à marcha do mundo e à sorte, Schopenhauer reproduz muitas das idéias constantes em Especulação transcendente sobre a aparente intencionalidade no destino do indivíduo. As sete máximas que ele apresenta nesse item advertem-nos sobre o poder do destino e da sorte na nossa vida individual, e nos mostram as conseqüências para nossa conduta. Debruçar-nos-emos sobre três delas, que são as mais dignas de nota. A primeira é a quadragésima oitava máxima, segundo a qual, dos três poderes que dominam o mundo, prudência, força e fortuna, esta última é a mais influente. Seu poder advém de que, à revelia de nossos esforços, a fortuna nos aproxima ou nos afasta de nossos intuitos, a seu bel prazer. Em virtude disso, o filósofo aconselha não esperarmos que a sorte nos dê algo por reconhecer méritos, nem ofereça segurança. Devemos fazer planos e nos aproximar deles segundo as circunstâncias, conscientes de que o curso de nossa vida é produto de dois fatores, que são a série dos fatos e a de nossas

\footnotetext{
75 Ibidem, p. 193.

${ }^{76}$ Ibidem, p. 194.

77 Ibidem, p. 203.
} 
decisões ${ }^{78}$. Nesse aspecto, diz ele, “as coisas se passam na vida como no jogo de xadrez; nós combinamos um plano, que fica ademais subordinado ao que queira fazer nosso adversário, que na vida é a sorte" 79 .

A quadragésima nona máxima, que preceitua prudência e a consciência de que as coisas são mutáveis no decurso do tempo, mostra que o mundo é constituído por inúmeras cadeias causais que não param no tempo, de maneira que não podemos nos deixar enganar com a aparência das coisas. Assim, diz Schopenhauer, "o homem prudente é aquele a quem a estabilidade aparente não engana e que prevê, ademais, a direção em que a mudança próxima se dará ${ }^{\prime 0}$. Finalmente, a qüinquagésima primeira máxima nos diz que devemos evitar os excessos de alegria ou de lamentações nos acontecimentos da vida. As circunstâncias são inconstantes, podem mudar a qualquer momento, e nosso juízo é falho, enganando-se amiúde sobre o que nos é ou não prejudicial. É preciso manter a tranqüilidade em todas as contrariedades, diminuir nossas pretensões e aceitar as imperfeições das coisas. Devemos cultivar o "sentimento estóico que impulsiona a jamais ser conditionis humanae oblitus ${ }^{81}$, e sempre recordar o triste e deplorável destino da existência humana, assim como o número infinito de sofrimentos a que está exposta" 82 . A calma perante os sofrimentos que nos acometem deve provir da convicção de que tudo ocorre necessariamente, pois, diz Schopenhauer, é mais fácil resignarmo-nos em relação a algo inevitável.

\section{Considerações finais}

A partir das idéias precedentes, observamos que Kant se empenha em encontrar aquilo que possa obrigar a vontade a agir contra a inclinação natural, considerada patológica e que, via de regra, nos compele para a direção contrária à ação moral. A convicção acerca da imperfeição humana leva-o a repelir todas as ações advindas dessa natureza, ainda que fossem boas e conformes ao dever. Kant encontra somente no imperativo categórico, fundamentado na razão, a certeza de que a ação será feita por dever

\footnotetext{
78 Ibidem, p. 208.

79 Ibidem, loc. cit.

${ }^{80}$ Ibidem, p. 210.

81 "Esquecidos da condição humana". Ibidem, p. 213.

${ }^{82}$ Ibidem, loc. cit.
} 
sendo, portanto, moral. Assim, seria necessário dominarmos as inclinações naturais pois, como afirma Bréhier, “[...] a moral não nos põe em harmonia com a nossa natureza; ela deve expulsá-la. A natureza, no sistema de Kant, não conduz mais à moralidade do que a física conduz à metafísica" ${ }^{83}$. Na medida em que o fenômeno, também para Kant, é regido pela lei de causalidade, a liberdade é exigida para que se possa quebrar as ilações causais no âmbito natural e para que o agente moral possa iniciar em si uma cadeia, com independência das condições antecedentes e da sensibilidade. Desse modo, para que a razão seja prática, exige-se a liberdade, e justamente por esta ser postulada, abre-se a possibilidade de que nossas ações acrescentem algo à realidade, isto é, de que elas não sejam meramente elos em uma cadeia causal alheia à nossa vontade. As considerações de Bréhier sobre isso são interessantes:

[...] longe de ser inumana e absurda, ela [a moral kantiana] nos fará sentir o profundo absurdo das doutrinas que enquadram o homem em uma tradição ou um meio, nos quais ele se compraz pela inércia e pela preguiça; [...] ensinar-nos-á que ele [o progresso] só pode ser fruto de nossa iniciativa própria e de uma espontaneidade radical da nossa vontade. Nosso destino é nossa obra e é só aparentemente que ele resulta necessariamente do antecedente ${ }^{84}$.

Para Schopenhauer, a razão simplesmente não é capaz de fundamentar ações morais, nem de possibilitar que se dêem atos com independência das condições antecedentes. A ação moral não é necessariamente racional, e a razão não introduz, nos atos, nenhuma liberdade. As ações morais, para o filósofo, resultam da visão através do princípio de individuação, um conhecimento que é intuitivo e dado em graus distintos de clareza, sem que o filósofo atribua expressamente liberdade a elas. A razão não pode, segundo Schopenhauer, desbaratar as inclinações da nossa natureza sensível. As ações racionais, por seu turno, são aquelas nas quais, após reflexão sobre o curso do mundo e sobre as potencialidades individuais específicas, o homem busca as melhores e mais eficazes maneiras de satisfazer sua vontade.

De uma parte, ao alcançarmos mais clareza em relação ao nosso caráter individual, isto é, ao obtermos um caráter adquirido, avançamos na satisfação racional da nossa vontade e temos mais chances de sermos bem-sucedidos nos nossos intentos. Isso porque, ${ }_{83}$ BRÉHIER, E. op cit., p. 79.

${ }^{84}$ Ibidem, p. 80. 
diz Schopenhauer, “[...] não bastam o simples querer ou poder por si sós, mas uma pessoa tem também que saber o que quer e saber o que pode: só assim mostrará caráter, e só então

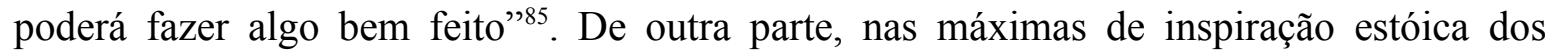
“Aforismos", em que Schopenhauer expõe algumas convicções de sua filosofia sobre a direção dos eventos no mundo, avançamos na compreensão das situações reais em que vivemos. Na medida em que conhecermos essas condições, avaliaremos melhor as circunstâncias e tomaremos as melhores decisões. Assim, nos diversos momentos de nossa vida, teremos mais clareza sobre o melhor a fazer, se fixarmos em máximas abstratas alguns aspectos de sua filosofia - buscar a ausência de dor e não o prazer; humildade quanto às nossas pretensões; saber o que queremos e o que podemos; conhecer a necessidade dos eventos do mundo e a invariabilidade dos caracteres; sermos abstinentes e indulgentes; educarmo-nos com máximas abstratas; não confiar na fortuna e fazer planos.

Destarte, as ações por máximas abstratas e a razão no uso prático, para Schopenhauer, não implicam liberdade. A chave para a compreensão disso está em que a aquisição de um caráter artificial depende de um conhecimento de nós mesmos e das circunstâncias exteriores, possível apenas no transcurso do tempo. Ou seja, só conseguimos tal conhecimento a posteriori, conforme nos vemos nas diversas situações pelas quais passamos em nossa vida. Como escreve Jair Barboza, "no íntimo, a decisão da Vontade é indeterminada ao espectador. A escolha só entra na consciência após a decisão. Somos espectadores de nós mesmos" ${ }^{\text {" }}$. Nesse sentido, aplicar a razão à vida prática e alcançar o conhecimento de nossa individualidade equivale a conhecermos melhor as circunstâncias empíricas. Equivale a ir, ao longo do tempo, corrigindo o conhecimento a respeito do mundo e de nós mesmos, de tal modo que aprendemos a não tomar decisões contra nossa tendência transcendental.

\section{Referências}

SCHOPENHAUER, A. El Mundo como Voluntad y Representación. Trad. de Rafael-José Fernández y M. ${ }^{\mathrm{a}}$ Montserrat Armas Concepción, Madrid: Akal Editores, 2005.

\footnotetext{
85 SCHOPENHAUER, A. MVRI, § 55, p. 330.

${ }^{86}$ BARBOZA, J. "Na fronteira do transcendental com o empírico. Metafísica e imanência em Schelling e Schopenhauer". In: SALLES, João Carlos (org.). Schopenhauer e o idealismo alemão, Salvador: Quarteto, 2004, p. 92.
} 
. El Mundo como Voluntad y Representación: Volumen segundo, que contiene los complementos a los quatro livros del primeiro volumen Trad. de Rafael-José Fernández y M. ${ }^{a}$ Montserrat Armas Concepción, Madrid: Akal Editores, 2005.

. O mundo como vontade e representação, parte III; Crítica da filosofia kantiana; Parerga e paralipomena, cap. V, VIII, XII, XVI. Trad. de Wolfgang Leo Maar e Maria Lúcia M. O. Cacciola, São Paulo: Victor Civita, 1985 (Os pensadores).

. Parerga y paralipomena I. Trad. Antonio Zozaya. Málaga: Agora, 1997.

. Sobre o fundamento da moral. Trad. de Maria Lúcia M. O. Cacciola $1^{\text {a }}$ ed., Martins Fontes, São Paulo, 1995.

BARBOZA, J. "Na fronteira do transcendental com o empírico. Metafísica e imanência em Schelling e Schopenhauer". In: SALLES, João Carlos (org.). Schopenhauer e o idealismo alemão, Salvador: Quarteto, 2004.

BRÉHIER, E. Histoire de la philosophie allemande. $3^{\mathrm{a}}$ ed., Paris: VRIN, 1954.

CACCIOLA, M.L. "O intuitivo e o abstrato na filosofia de Schopenhauer". In: SALLES, João Carlos (org.). Schopenhauer e o idealismo alemão. Salvador: Quarteto, 2004.

DELEUZE, G. A filosofia crítica de Kant. Trad. de Germiniano Franco, Lisboa: Edições 70, 2000.

KANT, I. Crítica da Razão Prática. Trad. de Valério Rohden.1 $1^{a}$ ed., São Paulo: Martins Fontes, 2003.

\section{$\overline{\text { Lisboa, } 1986 .}$}

. Fundamentação da Metafísica dos Costumes. Trad. de Paulo Quintela, Edições 70,

KÜLPE, O. Kant. Trad. de Domingo Miral López. $3^{\text {a }}$ ed., Barcelona: Labor S.A., 1939.

Recebido: 10/11/11

Received: 11/10/11

Aprovado: 24/01/12

Approved: 01/24/12 